\title{
Biodiversity through Domestication
}

Examples from New Guinea

Biodiversité et domestication: exemples de Nouvelle-Guinée

\section{Wulf Schiefenhövel}

\section{(2) OpenEdition}

\section{Journals}

Electronic version

URL: http://journals.openedition.org/ethnoecologie/1459

DOI: $10.4000 /$ ethnoecologie. 1459

ISSN: 2267-2419

\section{Publisher}

Laboratoire Eco-anthropologie et Ethnobiologie

Electronic reference

Wulf Schiefenhövel, «Biodiversity through Domestication », Revue d'ethnoécologie [Online], 3 | 2013, Online since 12 November 2013, connection on 21 April 2019. URL : http://journals.openedition.org/ ethnoecologie/1459; DOI : 10.4000/ethnoecologie.1459

This text was automatically generated on 21 April 2019

\section{c) (i) $(9$}

Revue d'ethnoécologie est mis à disposition selon les termes de la licence Creative Commons Attribution - Pas d'Utilisation Commerciale - Pas de Modification 4.0 International. 


\title{
Biodiversity through Domestication
}

\author{
Examples from New Guinea \\ Biodiversité et domestication : exemples de Nouvelle-Guinée
}

Wulf Schiefenhövel

\section{Introduction}

1 The goal of this contribution is to show the extent to which biodiversity was enriched in some 8,000 years of New Guinean and Island Melanesian horticulture and plant domestication and to show that these rich agroecosystems are under threat.

\section{Domestication of food plants}

2 Since the onset of plant domestication approximately 12,000 years before present, this process took place on a relatively large scale in only a limited number of centres in the world. Purugganan \& Fuller (2009) mention 13 such centres ${ }^{1}$, which is probably fewer than the actual number.

3 Important centres were, with the major plants (this list is evocative, not comprehensive):

1) The Fertile Crescent (Iraq, western Iran, south-eastern Turkey, Syria, Jordan, Lebanon, Israel, Palestine and Egypt), where einkorn wheat (Triticum monococcum), dinkel (T. aestivum spelta) and emmer wheat (T. turgidum), which are the precursors of wheat (T. aestivum vulgare), were cultivated, as well as barley (Hordeum vulgare) (cf. Fuller 2007, Zohary \& Hopf 2000) - a success story after a non-promising beginning, during which health declined in comparison to hunter-gatherer existence (Mummert et al. 2011).

2) China, with rice (Oryza sativa subsp. japonica and indica), several species of millet ( Echinochloa crus-galli, Panicum miliaceum, Setaria italica), buckwheat (Fagopyrum esculentum) and others (Crawford 2006). 
3) India, with legumes such as Vigna radiata, V. mungo and horsegram (Macrotyloma uniflorum), as well as small millets (Brachiaria ramosa, Setaria verticillata) and other foods such as sesame (Sesamum indicum) (Fuller 2011).

4) Europe, where oats (Avena sativa, the non-domesticated ancestor of which is native to the Near East) and a number of fruits and vegetables (such as plum Prunus domestica, cherry Prunus cerasus, cabbage Brassica oleracea, and parsnip Pastinaca sativa) were domesticated (Zohary \& Hopf 2000).

5) Africa, with pearl millet (Pennisetum glaucum) and African rice (Oryza glaberrima) in West Africa and Sorghum bicolor and Eleusine coracana in the eastern savannahs or Ethiopia. Other plant foods domesticated in Africa include oil palm (Elaeis guineensis) and several yams (Dioscorea rotundata, D. cayenensis) (cf. Fuller 2007, Bower 1991).

6) The Americas, with an astounding, worldwide unique number of very different domesticated plants, many of them highly important as food in the globalised world. Several centers are recognized (Piperno 2011, Smith 2011):

- Southwestern North America, sunflower (Helianthus annuus), squash (Cucurbita pepo)

- Central America, maize (Zea mays), beans (Phaseolus spp.), chile (Capsicum annuum), squash (Cucurbita moschata), tomato (Solanum lycopersicum), sweet potato (Ipomoea batatas) ${ }^{2}$ ...

- Andes, potato (Solanum tuberosum), quinoa (Chenopodium quinoa), peanut (Arachis hypogaea), squash (Cucurbita maxima)...

- Amazonia, cassava (Manihot esculenta), yam (Dioscorea trifida), cocoyam (Xanthosoma sagittifolium), chile (Capsicum chinense)...

and, in the last decades, to many researchers' surprise

7) New Guinea and its surrounding Melanesian islands, with a rich list of plants domesticated in this part of the world (see below). Originally it was thought that the manifold food plants of New Guinea and wider Melanesia were either imports from South-East Asia or unintentional transfers by humans.

\section{Highland New Guinea as a cradle of early agriculture - birth of a revolutionary insight}

Only recently has New Guinea, in particular its highlands, become recognized as a veritable centre of early agriculture (in this case horticulture) and an equally successful arboriculture. The first scholars who demonstrated that New Guinea and the surrounding islands were actually a hub of very early plant cultivation and domestication were Barrau $(1959,1962,1965)$ and Yen $(1974,1991,1995,1996,1998)$, Yen \& Wheeler $(1968)$ as well as Golson and his team, who discovered, by careful archaeological work and pollen analysis, 
that at Kuk in the Wahgi Valley not far from Mount Hagen, the Papuans had started, about $8,000 \mathrm{ybp}$, to grow taro on large drained garden plots $(1976,1977,1991)$. This discovery was really a sensation and turned the eye on highland New Guinea as a cradle of agriculture in this far-away corner of the earth.

Despite these findings, well-known anthropologists such as Matthew Spriggs (1997) and linguists such as Bellwood (1985) were convinced that “... the origins of agricultural systems... must be sought... on the Asian mainland" (Spriggs 1997: 534), i.e. not even in the Southeast Asian archipelagos such as Indonesia. Yet, it is now well established that a number of food plants, some of them subsequently imported in many countries and economically important, are the product of early Papuan gardening and domesticating skills (Lebot 1999, Neumann 2003, Denham et al. 2004, Bourke 2001, 2009, Denham 2011), among them the following:

- sugar cane (Saccharum officinarum);

- sayur lilin in Bahasa Indonesia, respectively pitpit in Neomelanesian Pidgin (Saccharum edule);

- taro (Colocasia esculenta) and other Araceae (Cyrtosperma chamissonis, Alocasia macrorrhiza );

- yams (Dioscorea bulbifera and D. alata); Figures $1 \& 3$.

- banana (Musa spp., comprising Australimusa and Eumusa, cf. Perrier et al 2011);

- two or more Setaria species (Setaria palmifolia, S. plicata...);

- probably Rungia klossii, a green leafy vegetable with high contents of protein and minerals;

- sago (Metroxylon sagu, possibly also other species);

- several species of the genus Pandanus (e.g. P. brosimos and P. conoideus);

- breadfruit (Artocarpus altilis);

- the so-called Tahitian chestnut (Inocarpus fagifer);

- several other nut-bearing trees, including the Okari nut (Terminalia kaernbachii) and nuts of the genera Canarium and Spondias;

not to forget, probably domesticated in island Melanesia or Polynesia,

- the coconut (Cocos nucifera).

This is a truly impressive list. 
Figure 1. Filling in yams (tetu, Dioscorea alata) into the storage houses (liku) after a competitive harvest, Tauwema village, Trobriand Islands

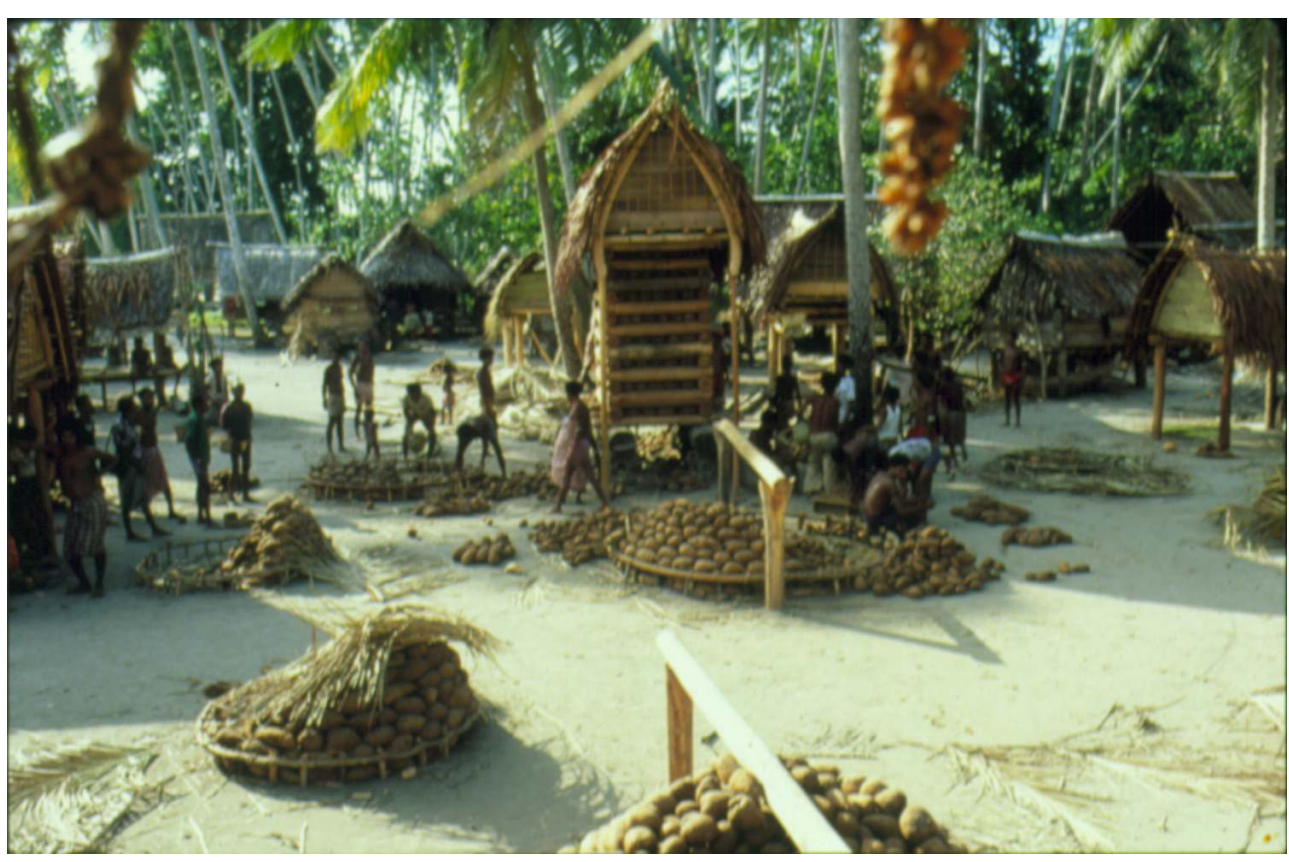

(c) W. Schiefenhövel

Figure 2. Planting yams (tetu, Dioscorea alata) in a coral garden, Trobriand Islands

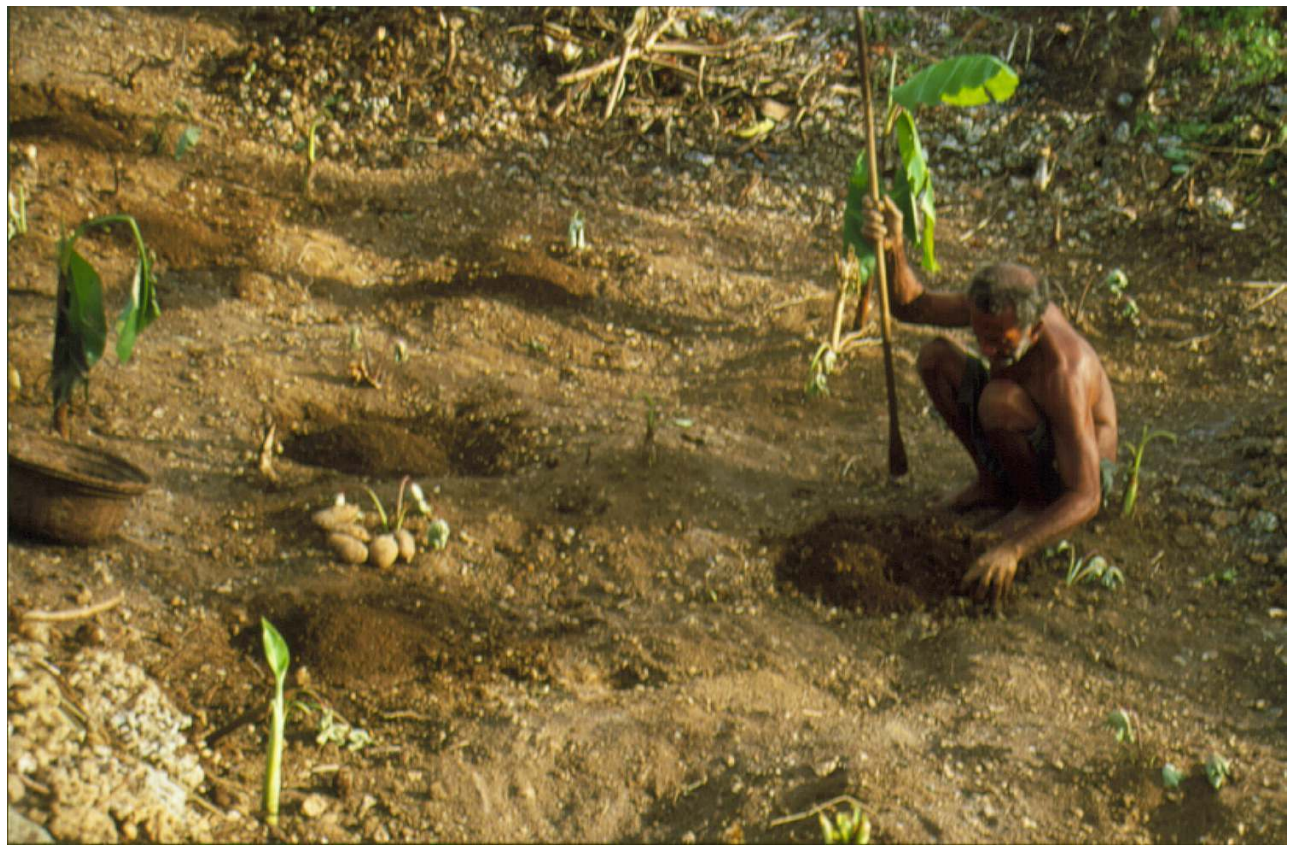

(c) W. Schiefenhövel 
Figure 3. Returning home with garden produce, mainly sweet potatoes and green vegetables, Eipomek, Papua Province, Indonesia

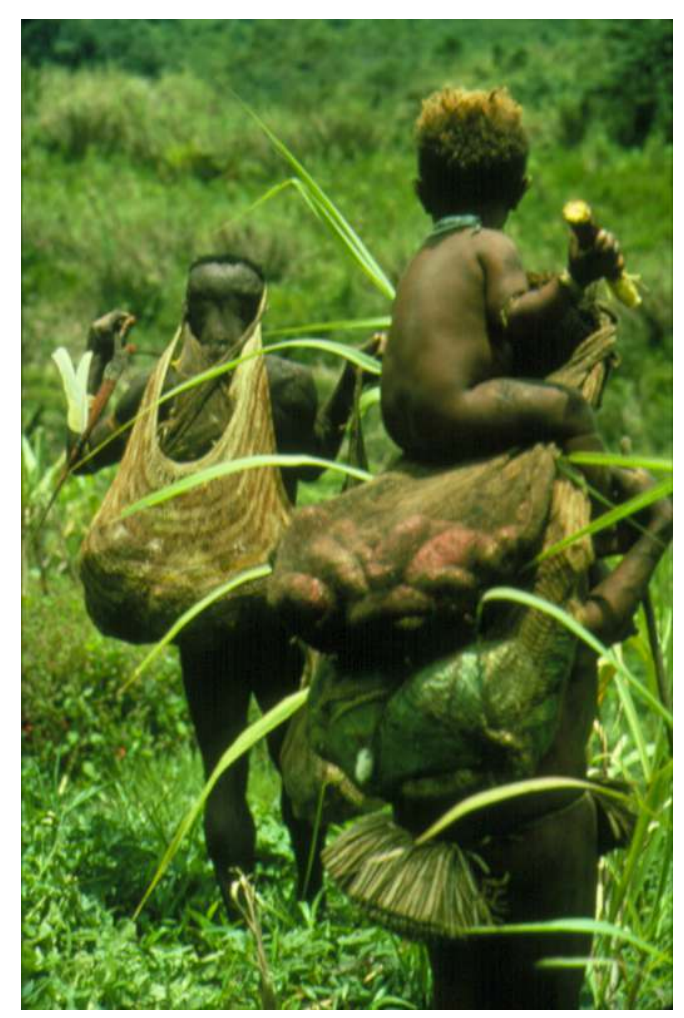

THE ONE YEAR OLD BOY EATS SUgAR CANE (KUYE, SACCHARUM OFFICINALE, DOMESTICATED IN THE HIGHLANDS OF NEW GUINEA)

(c) W. SCHIEFENHÖVEL

The early visitors of inland New Guinea, like the Leahy brothers who discovered the very populous Wahgi Valley with large fields of highly developed horticulture, hitherto completely hidden from the world (Leahy \& Crain 1937), were struck by their finding that the indigenous inhabitants of this remote part of the globe were accomplished agriculturists.

7 There is some debate on how these various processes of cultivation and domestication actually occurred, and on the steps that might have preceded the actual botanical change in the wild species which came under the power of the human mind and hand. In the context of this paper, such considerations are not very important, nor is the question whether Island New Guinean, Melanesian horticulture was an offspring of Papuan gardening success, as Jim Allen et al. (1988), Peter White (1992), Jim Specht (2007) and others claim, or whether, as Mathew Spriggs (1997) also spells out quite strongly, it was an import of Austronesian Lapita peoples, the newcomers of only about 3, - 4,000 ybp who were accomplished producers of pottery and amazing seafarers and navigators in open sailing canoes. These discussions will probably be resolved as soon as more data are available and the majority of the scientific community accepts their analysis. Manfred Kayser et al. $(2000,2003)$ have shown that the classic "Fast Train to Polynesia" model developed by archaeologists and linguists (e.g. Bellwood 1985) must be replaced by what Kayser and his team call the "slow Boat" model: Population microbiology demonstrates that the Austronesian newcomers picked up quite a substantial amount of Papuan genes before they went, as a mix between the original and the immigrant population, further 
into the vastness of the Pacific Ocean, in many waves and very slowly (and with more Ychromosome genes from Papuan men than from the original Asian men). Coming back to plants: Generally, it is a close to a miracle that archaeology and archaeobotany have made such good progress in one of the wettest regions of the world to uncover so many proofs of early highland New Guinean and Melanesian agriculture (Kayser et al. 2000, 2003).

Figure 4. Distribution of betel nut (bua, Areca catechu) at a feast, Tauwema village, Trobriand Islands

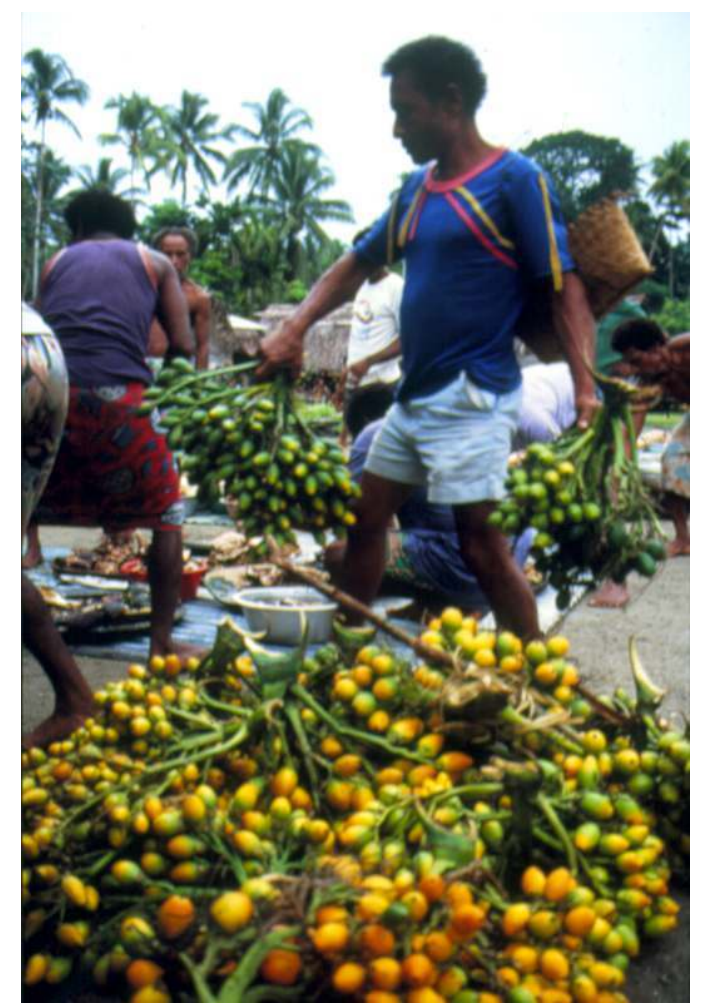

(c) W. Schiefenhövel

\section{Eipo horticulturists as natural scientists}

8 When, in July 1974, our team of five German fieldworkers arrived in the isolated valley of the Eipomek River, it soon became clear that the wish to have an airstrip for small singleengine airplanes existed on both sides. For a successful continuation of the interdisciplinary project "Man, Culture and Environment in the Central Highlands of West-New Guinea", sponsored by the German Research Foundation (DFG), it was essential to have access by aircraft. It had taken our team almost five days of often demanding walks over mountain passes and very rugged terrain to reach our destination. This was due to the fact that our long lindworm of approximately 50 female and male carriers and the few scientists was painfully slow. My wife Grete and myself, accompanied by some Eipo villagers, later covered the same distance in 14 hours, a single day, but that was a clear exception. Newcomers arriving from Germany would, as a rule, not be able to do that. The transport of equipment posed another problem: hence the decision to construct a landing strip. That became, apart from treating patients and discovering the secrets of the complex Papuan language, my job. To our surprise, the Eipo themselves were very keen as well to have access to the outside world. Much later, their strategy became clear. 
The knew that east, west and south of their valley American and European missionaries, bol kurunang in their language, the rose-coloured people, had built airstrips and that a new kind of life had started in these places. The Eipo had begun to understand that they lived, so to speak, in a tiny bubble at the fringe of the world, forgotten, as it were, by time. And they wanted to get out of this bubble. They saw us as mediators in the difficult process of getting access to the world. An airstrip, they knew, was instrumental for this goal. They thus quite willingly helped in the Herculean task of constructing, with just a handful of spades and two crowbars, a landing strip, $366 \mathrm{~m}$ long, with an incline of about $6 \%$. Just enough to allow the mission Cessnas to land and take off.

9 The classic payment in those days was salt. One needed very little, a spoonful for a day's work and it was easily available at the coast. As a medical doctor, I had problems with this mode of compensation as I knew that the indigenous people of Highland New Guinea have very little or no access to mineral sodium chloride and I was worried that changing this important part of their diet would lead to unwanted consequences, raised blood pressure being the most important of them. So, we looked for an alternative form of payment. We decided to use peanuts instead. They were also rather cheap and could be bought in bulk in the wholesale stores of Jayapura, the then still rather sleepy capital city of the Province. The Eipo were very happy with their pay: one cup for a day's work. They roasted the little "nuts" on wooden sticks (actually they hardly eat any raw food, except sugar cane) and found them tasty - probably partly because of their fat content. Fat was very rare in their diet. The carefully raised few pigs were slaughtered only at special occasions and vegetable fat was only seasonally available when the large compound fruits of Pandanus brosimos were harvested in the mountains high above the valley or when, rarely, someone brought red Pandanus conoideus from the region further downstream. 
Figure 5. Steaming red Pandanus (ken, Pandanus conoideus) in the earth oven. Eipomek, Papua Province, Indonesia

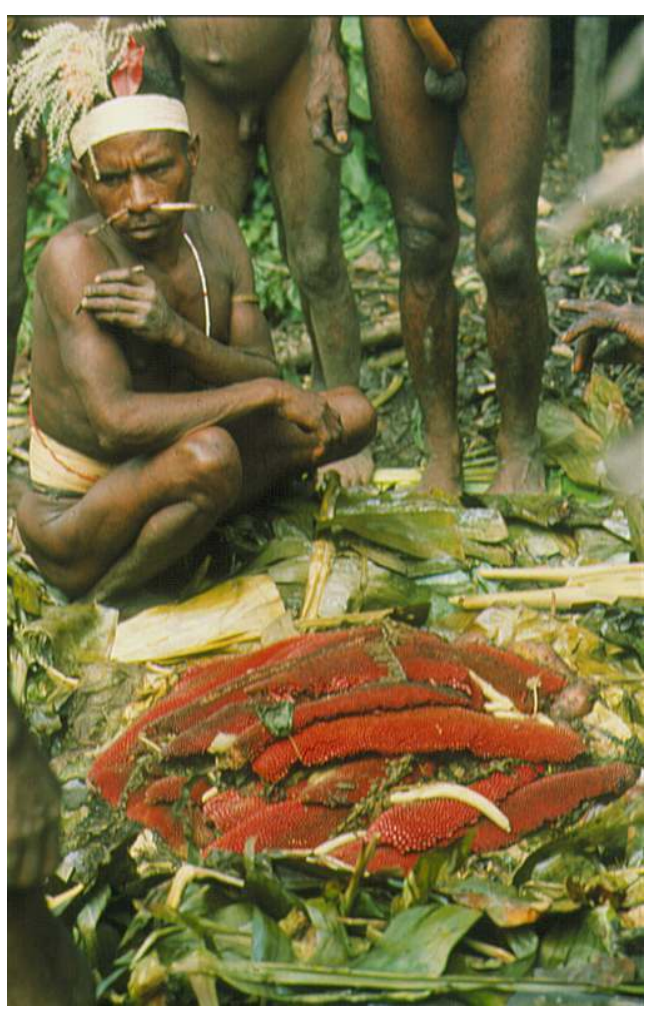

NUTRITIONALLY AND SYMBOLICALLY THIS IS IMPORTANT RARE FOOD

(c) W. Schiefenhövel 
Figure 6. Squeezing the steamed Pandanus between hands produces a very much appreciated sauce. Eipomek, Papua Province, Indonesia

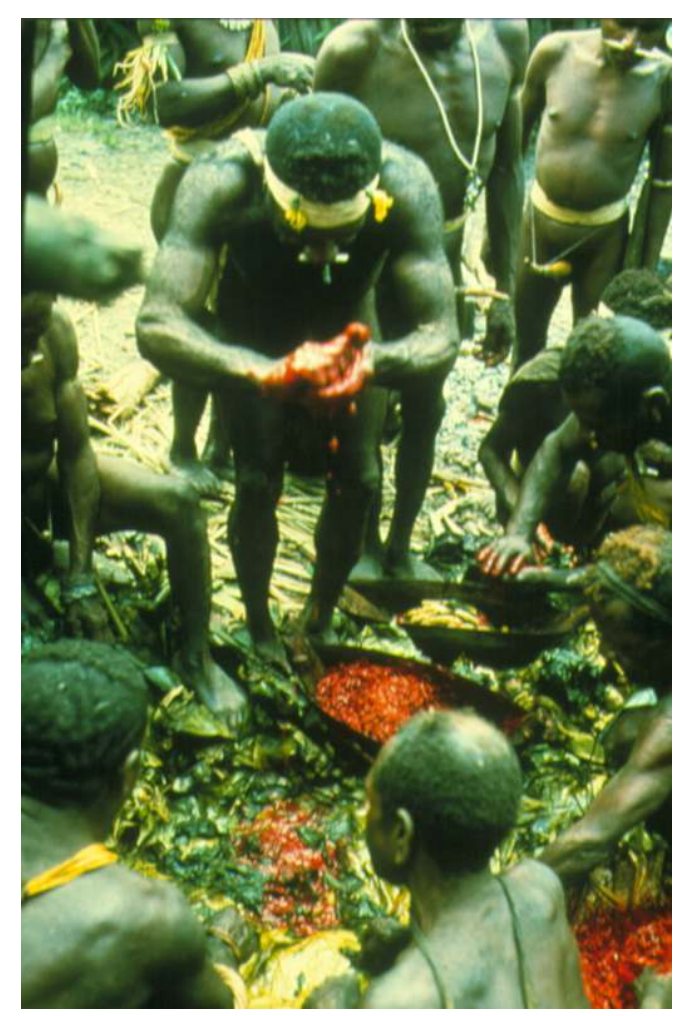

IN THE EARTH OVEN ARE MAINLY VEgETABLES (TOWA, ABELMOSCHUS MANIHOT; MULA, RUNGIA KLOSSI; AND BACE, SACCHARUM EDULE)

(C) W. SCHIEFENHÖVEL Botanical Garden, were sometimes outperformed by the locals when it came to taxonomy. We have reported elsewhere (Hiepko \& Schiefenhövel 1987) about this extraordinary feat of natural science, of the astounding precision of taxonomic concepts in the field of cognitive anthropology. Papuans have very clear ideas about the relationship of the magnitude of plants (all known by name) in their environment. And the most stunning thing is that their classification is ours - the Linnaean system of hierarchy and relatedness. The latter is still the basis of modern botany (despite the influence and sometimes correcting effect of molecular genetics) and it is based on 
morphological criteria. That is exactly what the Eipo do when they say that plant $\mathrm{X}$ is "the brother" or the "uncle" of plant " $Y$ " or " $Z$ ". In short, it is obvious that the Eipo, like other Highland Papuans, are not only keen and gifted gardeners but also natural scientists when it comes to understanding the world of plants and animals. This, being gifted with "green fingers" and a "green mind", I am sure, must have been the reason why, approximately 8,000 years ago, their ancestors started to domesticate quite an impressive number of plants. Such an isolated place on our planet, surrounded by the Pacific and cut into steep valleys by rugged, alpine mountains of up to 5,000 m elevation, became one of the few world centres for agriculture - no wonder that, for a long time, that was unthinkable. Scientists were convinced that the food plants of New Guinea's peoples all had been imported from the Indonesian cultures or from even further west and north of the big island.

\section{Conclusion}

Human-made biodiversity has become an acknowledged fact for highland New Guinea. In the case of sugar cane, for instance, the situation is convincingly clear. There are three sympatric species: Saccharum spontaneum, the non-edible wild form, a domesticated edible form frequent mainly in New Guinea, S. edule, and the classic domesticated S. officinarum, which most people might think is a plant native to Cuba. Most probably the original flora of New Guinea and Melanesia in general offered good chances for human interference with naturally growing plants. It is an interesting question whether the very impressive success of Amerindian peoples with plant domestication (less so with animal domestication, even though there are some examples) is due more to a flora facilitating the selection of plants to become changed by human interference or whether this extraordinary performance is due to particular human factors, such as highly skilled botanical techniques and, as in the case of the Papuans, highly developed botanical knowledge. Most likely, both factors must be present and will, in concert, so to speak, bring about success in mastering plant domestication.

14 Very interesting is the question of what steps were actually necessary to transform hunter-gatherers and, at the coast or in the lowlands, collectors of aquatic and marine resources to gardeners. An intermediate stage might have been what Guddemi calls (1992) "hunter-horticulturism". Serge Bahuchet, Doyle McKey and Igor de Garine have discussed (1991) the question of whether human disturbance of the "natural" environment may not be so pronounced that some plants can actually not grow in completely undisturbed habitats. They also ask the more general question, whether forest dwellers can survive without contacts to agriculturally living groups from whom they can (like nomads who have a lot of meat and milk-products) receive starchy foods to fulfil the need for energy. For New Guinea, the scenario seems clear: The early immigrants to this part of the world had no access to horticultural products because that form of subsistence was only developed about 40,000 years later. Perhaps Metroxylon, perhaps other wild starch-providing trees or other plant species, not yet cultivated and domesticated, might have provided the carbohydrates usually important for humans - except for the Inuit and some other arctic groups who depend more on (animal) fat.

Ethnographic and ethnobotanical fieldwork among the Eipo, typical Papuans of Highland New Guinea (Schiefenhövel 1976, 1991) with an astounding knowledge about plants and animals, demonstrates that mental maps concerning the flora in their mountainous 
homeland and concepts of how to deal with selecting and growing suitable food plants must have been present for a long time in the history of these formerly neolithic people.

Access to the land of the Eipo from urbanised regions such as the north coast, where the provincial capital Jayapura is located, is by airplane only. This has, so far, protected them from many ill effects of acculturation. In particular, biodiversity has remained largely uninfluenced from outside. In terms of agricultural biodiversity, the exception is sweet potato, which reached the Highlands of New Guinea in the $17^{\text {th }}$ century, from the Americas, and was fully adopted by the populations (cf. Watson 1965, Rappaport 1977, Wiessner \& Tumu 1998).

Figure 7. Sweet potato (kwaning, Ipomoea batatas) garden, Kosarek, Papua Province, Indonesia

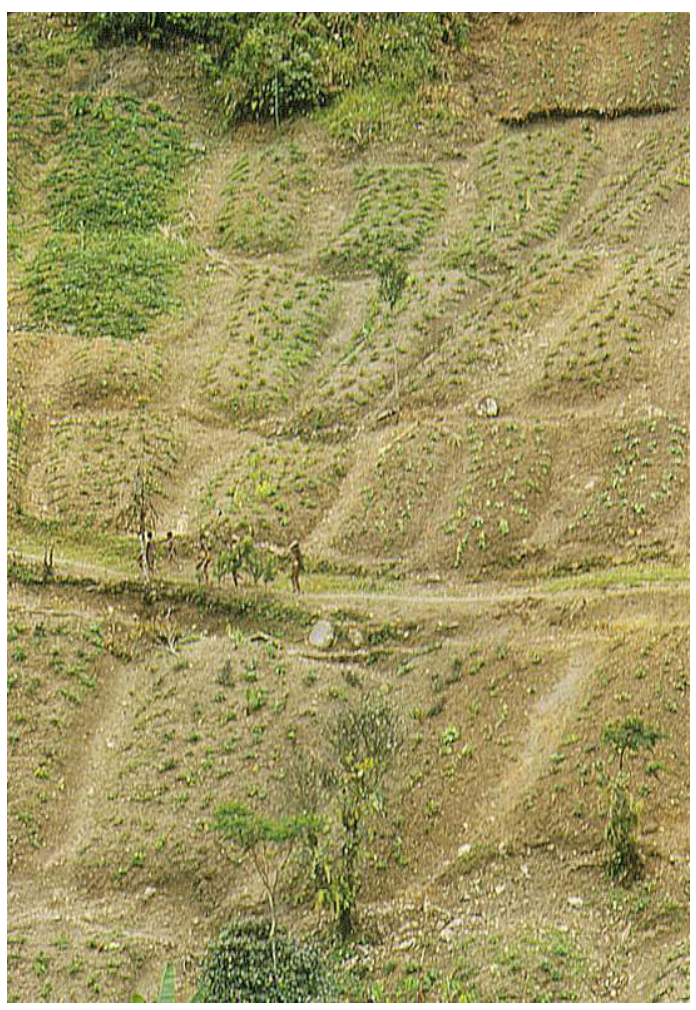

(c) W. SCHIEFENHÖVEL

Yet, some new cultivars and food plants, including chayote (Sechium edule), several types of imported bean species, maize (Zea mays), European cabbage cultivars, the "Irish" potato (Solanum tuberosum) and rhubarb (Rheum rhabarbarum), have been successfully adopted by the local people and are either grown for their own consumption or, to a still quite small degree, as cash crops. Their horticultural system has been made a bit more efficient by the use of shovels instead of the digging stick; due to population pressure, fallow times are also much shorter now than the approximately 15 years that was a typical fallow period previously. Most dramatic is the change concerning protein supply, which was extremely limited in the old times. Now, it has become a status symbol for a man to build up to 10 and more fishponds in which Chinese carp and another as yet unidentified species are very succesfully grown.

So far then, all these plant and animal imports do not seem to threaten the rich biodiversity in this remote area. Eventually, the influx of neophytes will become bigger and perhaps dangerous for the hitherto rather balanced flora. The biggest danger would 
be if one of the gigantic open gold and copper mines established elsewhere in New Guinea were to be established in this region. The Tembagapura mine with its coastal hub Timika near the south coast of the Province of Papua and the Oktedi mine in neighbouring Papua New Guinea are "a writing on the wall" warning of how quickly and completely an ecosystem will be destroyed. There are some plans to exploit, close to Oksibil, only about a 10-minute flight from Eipomek to the east, the two precious minerals which seem to sleep everywhere in the Papuan earth's bosom. One can only hope that this will not happen and that the local people will have enough insight and power to stem the tide. But, this is, of course, the view of a European. The Papuans of highland New Guinea may see the balance between gains and losses quite differently.

19 Logging and subsequent modern agriculture, e.g. the establishment of vast palm oil plantations, are probably the biggest threat to biodiversity (cf. Norgard 1988), in New Guinea as in Melanesia, Indonesia and Malaysia. Logging and plantation agriculture, however, require land or water transport, which fortunately is not yet available in the interior of the Star Mountains, Pegunungan Bintang. One day, though, the engineers might succeed in building roads through the very rugged and landslide-prone terrain, as they have done in the central highland around Wamena. Then, the Eipo will have to find new strategies to protect their biodiversity and their culture from becoming globalised and thereby threatened.

Figure 8. Modern times, dress-wise, but traditional steaming food in the earth oven (fito), Eipomek, Papua Province, Indonesia

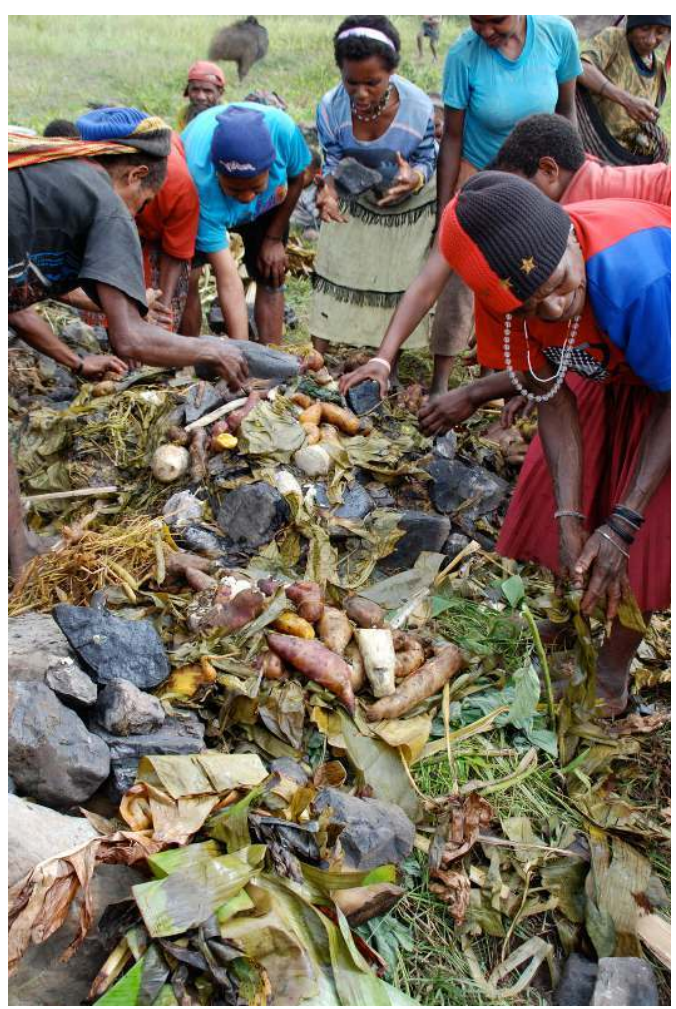

(C) W. SCHIEFENHÖVEL 


\section{BIBLIOGRAPHY}

Allen J., Gosden R. \& White P. 1988 - Pleistocene dates for human occupation of New Ireland, Northern Melanesia. Nature 331 : 707-709.

Bahuchet S., McKey D. \& Garine I. de 1991 - Wild yams revisited: Is independence from agriculture possible for rain forest hunter-gatherers? Human Ecology 19 : 113-243.

Barrau J. 1959 - The sago palms and other food plants of marsh dwellers in the Pacific Islands. Economic Botany 13 : 151-162.

Barrau J. (Ed.), 1963 - Plants and Migration of Pacific Peoples. Honolulu, Bishop Museum Press.

Barrau J. 1965 - Histoire et Préhistoire Horticoles de l'Océanie Tropicale. Journal de la Société des Océanistes $21: 55-78$.

Bellwood P. 1985 - Prehistory of the Indo-Malayan Archipelago. Sydney, Academic Press.

Bourke M.R. 2001 - Intensification of agricultural systems in Papua New Guinea. Asia Pacific Viewpoint 42 (2-3) : 219-236.

Bourke M.R. 2009 - History of Agriculture in Papua New Guinea. In Bourke M.R. \& Harwood T. Food and Agriculture in Papua New Guinea. Canberra, ANU E Press : 10-26 http://epress.anu.edu.au/ wp-content/uploads/2011/05/whole_book_Part_1.pdf (accessed in May and June 2011).

Bower J. 1991 - The pastoral Neolithic of East Africa. Journal of World Prehistory 5(1) : 49-82. DOI: 10.1007/BF00974732 http://www.jstor.org/stable/25800592 (accessed in May and June 2011).

Crawford G.W. 2006 - East Asian plant domestication. In Stark Miriam T. (Ed.) Archaeology of Asia. Malden, MA, Oxford, UK and Carlton, Victoria, Blackwell.

Denham T. 2011 - Early agriculture and plant domestication in New Guinea and island Southeast Asia. Current Anthropology 52(S4) : S379-S395.

Denham T., Haberle S. \& Lentfer C. J. 2004 - New evidence and revised interpretations of early agriculture in Highland New Guinea. Antiquity 78 (302) : 839-857.

Fuller D.Q. 2007 - Contrasting patterns in crop domestication and domestication rates: recent archaebotanical insights from the Old World. Annals of Botany $100: 903-924$

Fuller D.Q. 2011 - Finding plant domestication in the Indian subcontinent. Current Anthropology 52 (S4) : S347-S362.

Golson J. 1977 - No room at the top': Agricultural intensification in the New Guinea highlands. In Allen et al. (Ed.) Sunda and Sahul: Prehistoric Studies in Southeast Asia, Melanesia and Australia. New York and San Francisco, Academic Press : 601-638.

Golson J. 1991 - The New Guinea highlands on the eve of agriculture. Bulletin of the Indo-Pacific Prehistory Association $11:$ 82-91.

Golson J. \& Hughes P.J. 1980 - The appearance of plant and animal domestication in New Guinea. Journal de la Société des Océanistes : 294-303.

Guddemi P. 1992 - When horticulturalists are like hunter-gatherers: the Sawiyano of Papua New Guinea. Ethnology $31: 303-314$. 
Hiepko P. \& Schiefenhövel W. 1987 - Mensch und Pflanze. Ergeb-nisse ethnotaxonomischer und ethnobo-tanischer Untersuchungen bei den Eipo, Zentrales Bergland von Irian Jaya (West-Neu-guinea), Indo-nesien. Berlin, Reimer.

Hiepko P. \& Schultze-Motel W. 1981 - Floristische und ethnobotanische Untersuchungen im EipomekTal, Irian Jaya (West-Neuguinea), Indonesien. Berlin, Reimer.

Kayser M., Brauer S., Weiss G., Underhill P.A., Roewer L., Schiefenhövel W. \& Stoneking M. 2000 - Melanesian origin of Polynesian Y chromosomes. Current Biology 10 (20) : 1237-1246.

Kayser M., Brauer S., Weiss G., Schiefenhövel W., Underhill P., Peidong S., Oefner P., TommaseoPonzetta M. \& Stoneking M. 2003 - Reduced Y-chromosome, but not mitochondrial DNA, diversity in human populations from West New Guinea. American Journal of Human Genetics 72 : 281-302

Leahy M.J. \& Crain M. 1937 - The Land That Time Forgot. Adventure and Discoveries in New Guinea. New York, Funk \& Wagnalls.

Lebot V. 1999 - Biomolecular evidence for plant domestication in Sahul. Genetic Resources and Crop Evolution $46: 619-628$

Mummert A., Esche E., Robinson J. \& Armelagos G. J. 2011 - Stature and robusticity during the agricultural transition. Evidence from the bioarchaeological record. Economics and Human Biology $9: 284-301$

Neumann K. 2003 - New Guinea: a cradle of agriculture. Science 301 (5630) : 180-181.

Norgard R.B. 1988 - The rise of the global exchange economy and the loss of biological diversity. In Wilson E. O. \& Frances M. P. (Ed.) Biodiversity. Washington, D.C., National Academy Press : 206-211.

Perrier X., De Langhe E., Donohue M., Lentfer C., Vrydaghs L., Bakry F., Carreel F., Hippolyte I., Horry J.-P., Jenny C., Lebot V., Risterucci A.-M., Tomekpe K., Doutrelepont H., Ball T., Manwaring J., de Maret P. \& Denham T. P. 2011 - Multidisciplinary perspectives on banana (Musa spp.) domestication. Proceedings of the National Academy of Sciences 108 (28) : 11311-11318.

Piperno D.R. 2013 - The origins of plant cultivation and domestication in the New World Tropics: patterns, process, and new developments. Current Anthropology 52 (S4) : S453-S470.

Price T.D. \& Bar-Yosef O. 2011 - The origins of agriculture: new data, new ideas: an introduction to Supplement 4. Current Anthropology 52 (S4) : S163-S174.

Purugganan M.D. \& Fuller D.Q. 2009 - The nature of selection during plant domestication. Nature $457: 843-848$.

Rappaport R.A. 1977 - Pigs for the Ancestors; Ritual in the Ecology of a New Guinea People. New Haven, Yale University Press, $\mathrm{xx}+311 \mathrm{p}$.

Roullier C., Duputié A., Wennekes P., Benoit L., Fernández Bringas V.M., Rossel G., Tay D., McKey D. \& Lebot V. 2013 - Disentangling the origins of cultivated sweet potato (Ipomoea batatas (L.) Lam.). PLoS ONE 8(5/e62707) : 1-12. doi :10.1371/journal.pone.0062707.

Schiefenhövel W. 1976 - Die Eipo-Leute des Berglands von Indonesisch-Neuguinea: Kurzer Überblick über den Lebensrum und seine Menschen. Einführung zu den Eipo-Filmen des Humanethologischen Filmarchivs der Max-Planck-Gesellschaft. Homo 26 (4) : 263-275.

Schiefenhövel W. 1991 - Eipo. In Hays T. E. (Ed.) Encyclopedia of World Cultures, Volume II, Oceania. Boston, G.K.Hall \& Co : 55-59. 
Smith B. D. 2011 - The cultural context of plant domestication in Eastern North America. Current Anthropology 52 (S4) : S471-S484.

Specht J., 2007 - Small islands in the big picture: The formative period of Lapita in the Bismarck Archipelago. In Bedford S., Sand C. \& Connaughton S.P. (Ed.), Oceanic Explorations: Lapita and Western Pacific Settlement. Terra Australis 26. Canberra, ANU E Press : 51-70.

Specht J. 2009 - The aceramic to ceramic boundary in the Bismarck Archipelago. In Sheppard P.J., Thomas T. \& Summerhayes G.R. (Ed.), Lapita: Ancestors and Descendants, New Zealand Archaeological Association Monograph 28. Auckland: New Zealand Archaeological Association : 11-34. http://rspas.anu.edu.au/linguistics/ComparativeAustronesian/nzaa28_specht.pdf (accessed in May and June 2011).

Spriggs M. 1997 - The Island Melanesians. Cambridge, MA., Blackwell.

Watson J.B. 1965 - The significance of a recent ecological change in the central Highlands of New Guinea. The Journal of the Polynesian Society 74 (4) : 438-450.

White J.P. 1992 - New Ireland and Lapita. In Galipaud J-C. (Ed.) Poterie Lapita et peuplement. Nouméa, ORSTOM : 83-90.

Wiessner P. \& Tumu A. 1998 - Historical Vines. Enga Networks of Exchange, Ritual, and Warfare in Papua New Guinea. Washington, Smithsonian Institution, 494 p.

Yen D.E. \& Wheeler J.M. 1968 - Introduction of taro into the Pacific: the indications of chromosome numbers. Ethnology 7 : 259-267.

Yen D.E. 1973 - The origins of Oceanic agriculture. Archaeology and Physical Anthropology in Oceania $8: 68-85$.

Yen D.E. 1974 - Arboriculture in the subsistence of Santa Cruz. Economic Botany 28 : 2447-284.

Yen D.E. (1971) - The development of agriculture in Oceania. Pacific Anthropological Records 12 :

1-12.

Zohary D. \& Hopf M. 2000 - Domestication of Plants in the Old World. Oxford, Oxford University Press, $316 \mathrm{p}$.

\section{NOTES}

1. Interestingly, they do not list sugar cane (Saccharum edule) and other plants domesticated in Highland New Guinea (see below)!

2. Probably two centres of domestication, in Mesoamerica and northwestern South America (see Roullier et al. 2013).

\section{ABSTRACTS}

It is not widely known that Melanesia became a centre of horticulture and arboriculture about 8,000 years ago: taro (Colocasia esculenta, Cyrtosprema chamissonis, Alocasia macrorrhiza); sugar cane (Saccharum officinarum), a close relative called sayur lilin in Bahasa Indonesia, respectively pitpit in 
Neomelanesian Pidgin (Saccharum edule) of which the young inflorescence is eaten; yams (Dioscorea bulbifera and possibly other species like D. alata); banana (Musa spp., comprising Australimusa and Eumusa); two or more Setaria species (Setaria palmifolia, Setaria plicata...); beans of the genus Phaseolus; probably Rungia klossii and Abelmoschus manihot (cp. Okra, the also edible fruit of this plant), both green leafy vegetables with a high content of protein and minerals; sago (Metroxylon sagu, possibly also other species); several species of the genus Pandanus (e.g. P. brosimos and P. conoideus); breadfruit (Artocarpus altilis); the so-called Tahitian chestnut (Inocarpus fagifer); nut bearing trees like the Okari nut (Terminalia kaernbachii) and nuts of the genera Canarium and Spondias; coconut (Cocos nucifera) which was probably cultivated in island Melanesia or Polynesia. A number of these domesticated species, e.g. taro, sugar cane, Rungia klossii, other vegetables and nut-bearing trees were domesticated in isolated Highland New Guinea. Biodiversity was thus, by the gardening activities of ancestral Papuan peoples, increased in this part of the world. In some regions, which are not accessible by road as yet, this rich human-made biodiversity may survive for some time.

Il est peu connu que la Mélanésie fut un centre d'horticulture et d'arboriculture il y a environ 8000 ans : des taros (Colocasia esculenta, Cyrtosprema chamissonis, Alocasia macrorrhiza); la canne à sucre (Saccharum officinarum) et une espèce proche appelée sayur lilin en Bahasa Indonésie, et pitpit en Néomélanésien Pidgin (Saccharum edule), dont on consomme la jeune inflorescence; des ignames (Dioscorea bulbifera et probablement d'autres espèces comme D. alata); les bananes (Musa spp., y compris Australimusa et Eumusa); deux ou davantage d'espèces de Setaria (Setaria palmifolia, Setaria plicata...); des haricots du genre Phaseolus; probablement Rungia klossii et Abelmoschus manihot (le gombo, dont on consomme également les fruits), deux légumes feuilles à forte teneur en protéines et minéraux; le sagou (Metroxylon sagu, peut-être d'autres espèces); quelques espèces du genre Pandanus (comme P. brosimos et P. conoideus); l'arbre à pain (Artocarpus altilis); le "châtaignier" tahitien (Inocarpus fagifer); des arbres à fruits secs comme l'Okari nut (Terminalia kaernbachii) et d'autres des genres Canarium et Spondias; le cocotier (Cocos nucifera) qui fut probablement cultivé en Mélanésie ou Polynésie. Beaucoup de ces espèces domestiquées, comme le taro, la canne à sucre, Rungia klossii, et d'autres légumes et arbres à noix furent domestiqués dans les hautes montagnes isolées de Nouvelle-Guinée. La biodiversité fut donc enrichie dans cette partie du monde, par les activités de jardinage des peuples papous ancestraux. Dans quelques régions, non accessibles par la route jusqu'à aujourd'hui, la riche biodiversité créée par les hommes se maintiendra encore quelque temps.

\section{INDEX}

Population Papou

Mots-clés: biodiversité, ethnobotanique

Geographical index: Mélanésie, Nouvelle-Guinée, Highlands

Keywords: Melanesia, New Guinea, Highlands, Papuan, biodiversity, ethnobotany

\section{AUTHOR}

\section{WULF SCHIEFENHÖVEL}

Max-Planck-Institute Andechs - Human Ethology Group 